\title{
KRIMINALITETA KOT VSE POMEMBNEJŠI DEJAVNIK KAKOVOSTI BIVANJA V LJUBLJANSKI URBANI REGIJI
}

\author{
Barbara Lampič \\ Oddelek za geografijo, Filozofska fakulteta, Univerza v Ljubljani \\ Aškerčeva 2, 1000 Ljubljana, Slovenija. \\ e-mail: barbara.lampic@uni-lj.si
}

\begin{abstract}
Izvleček
Zaradi intenzivne suburbanizacije širše zaledje Ljubljane postaja izrazito prehodno območje z značilnim prepletanjem urbanih in ruralnih socialnogeografskih elementov. Med učinki suburbanizacije gotovo lahko obravnavamo tudi pojav in porast kaznivih dejanj. Podatki za leto 2002 kažejo, da je bilo v Ljubljanski urbani regiji zabeleženih dobrih $40 \%$ vseh kaznivih dejanj v Sloveniji. Daleč največ, skoraj 30 \%, v Mestni občini Ljubljana. Ogroženost se pomembneje povečuje v preostalih občinah Ljubljanske urbane regije, predvsem v tistih, ki jih je zajel zadnji val suburbanizacije.
\end{abstract}

Ključne besede: Splošna kriminaliteta, suburbanizacija, razširjenost kaznivih dejanj, Ljubljanska urbana regija

\section{CRIMINALITY AS AN INCREASINGLY IMPORTANT FACTOR OF THE QUALITY OF LIVING IN THE LJUBLJANA URBAN REGION}

\begin{abstract}
The increasingly extensive hinterland of Ljubljana is due to intensive suburbanization becoming an extremely transitional area with a typical intertwining of urban and rural sociogeographic elements. Among the effects of suburbanization we can certainly deal with the appearance and increase of criminal acts. The data for the year 2002 show that in the Ljubljana urban region there were registered more than $40 \%$ of all criminal acts in Slovenia. By far most of them, almost $30 \%$, were registered in the Ljubljana municipality. The endangerment is more notably increasing in the other communities of the Ljubljana urban region, above all in those which were captured by the last wave of suburbanization.
\end{abstract}

Key words: General criminality, suburbanization, extension of criminal acts, Ljubljana urban region 


\section{UVOD}

Ljubljanska urbana regija, kjer živi kar $25 \%$ celotnega prebivalstva Slovenije, z glavnim mestom predstavlja osrednje gospodarsko razvojno območje države. Zaradi intenzivne suburbanizacije vse širše zaledje Ljubljane postaja izrazito prehodno območje z značilnim prepletanjem urbanih in ruralnih socialnogeografskih elementov. Ti procesi so $\mathrm{v}$ preteklih desetletjih zajeli ožje območje oziroma občine v neposrednem ljubljanskem zaledju (Domžale, Brezovica, Vrhnika...), v zadnjem obdobju pa tudi širše vplivno območje Ljubljane (Ivančna Gorica, Velike Lašče, Komenda, Lukovica ...). Med učinki suburbanizacije gotovo lahko obravnavamo tudi pojav in porast kaznivih dejanj, predvsem kaznivih dejan zoper premoženje, ki z 88 \% v Sloveniji predstavljajo daleč najpomembnejši delež v strukturi kaznivih dejanj s področja t.i. splošne kriminalitete.

Slika 1: Struktura kaznivih dejanj v Sloveniji leta 2002

Figure 1: The structure of criminal acts in Slovenia in the year 2002

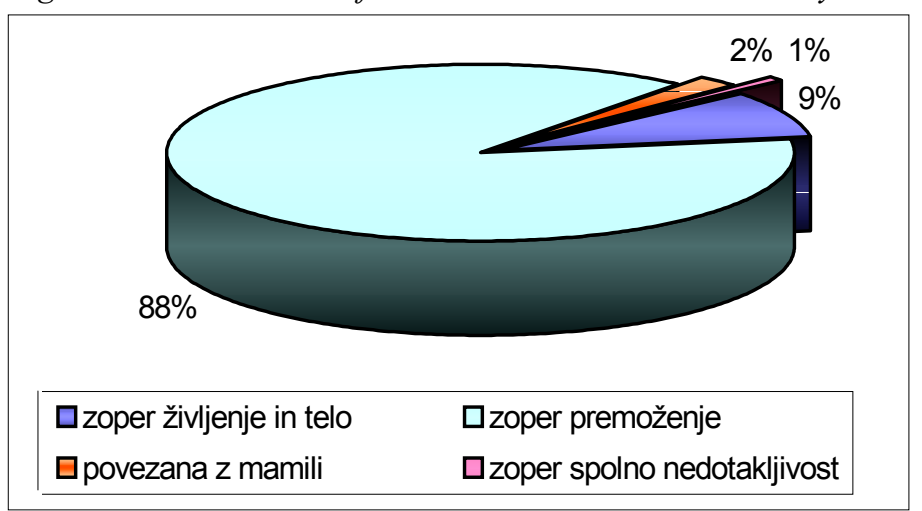

Vir: MNZ, 2003.

Kazniva dejanja v Sloveniji naraščajo, predvsem pa je izrazit njihov porast v Ljubljanski urbani regiji (LUR), kjer je njihov delež leta 2002 že presegel $40 \%$ vseh tovrstnih obravnavanih kaznivih dejanj v Sloveniji (še leta 2000 je ta delež znašal $36 \%$ ).

\section{KRIMINALITETA V LJUBLJANSKI URBANI REGIJI V PRIMERJAVI Z RAZMERAMI V SLOVENIJI}

Iskanje povezav med urbanim okoljem in določenimi vzorci obnašanja prebivalcev v geografiji še zdaleč niso nova. Kompleksnost povezav se kaže tudi v kriminalu kot obliki odklonskega vedenja. Pojav kriminalitete je tesno povezan z urbanim okoljem, najizraziteje s socio-ekonomsko diferenciacijo mesta. Porast števila kaznivih dejanj v srednji in vzhodni Evropi se pred- 
vsem v tujih raziskavah pogosto interpretira kot posledica tranzicije, učinka političnih, ekonomskih in kulturnih sprememb.

Podatki za Slovenijo kažejo, da je pojav kriminalitete pri nas le deloma povezan s temi procesi. Nasploh velja, da je Slovenija v primerjavi z drugimi evropskimi državami zmerno obremenjena s kriminaliteto, vendar se struktura in obseg kaznivih dejanj razmeroma hitro spreminjata (Svetek, 2003).

$\mathrm{Na}$ osnovi nekaterih podatkov o stopnji kriminalitete sredi preteklega desetletja smo za Ljubljano ugotavljali, da je še premajhno in notranje premalo diferencirano mesto, tako da $\mathrm{z}$ vidika kriminalitete ni bilo mogoče izdvojiti predelov, kjer so tovrstni delikventni pojavi izraziteje prisotni (Špes, Cigale, Lampič, 2002).

Po podatkih kriminalističnih služb se v Sloveniji zadnja leta kriminaliteta povečuje (skupaj je bilo obravnavanih kaznivih dejanj leta 1998 55.259, leta 2002 pa kar 77.218 (Svetek, 2003)), predvsem pa narašča število kaznivih dejanj s področja splošne kriminalitete. Pomembno je dejstvo, da narašča delež premoženjskih kaznivih dejanj (vse pogosteje z elementi nasilja), povečujejo se organizirane in s koristoljubjem pogojene oblike kriminalitete (tudi) mednarodnih razsežnosti, prihaja pa tudi do pomembnih prostorskih prerazporeditev kriminalitete in do dolgoročnih sprememb v vzrokih za nastanek kaznivih dejanj. Vzporedno v Sloveniji narašča tudi strah pred kriminaliteto (Svetek, 2003).

Zaradi spremenjene metode evidentiranja kaznivih dejanj podatki iz prejšnjega desetletja niso neposredno primerljivi s podatki o številu in vrsti kaznivih dejanj po letu 2000, hkrati pa od leta 1995 velja nov Kazenski zakonik RS, ki na novo opredeljuje 21 skupin kaznivih dejanj gospodarske in splošne kriminalitete. Tako sta analiza in prikaz dinamike spreminjanja po vrstah kriminalnih dejanj skupaj s prostorskimi prerazporeditvami za daljše obdobje za Slovenijo in manjše teritorialne enote teže izvedljiva.

Kot posledico suburbanizacije lahko obravnavamo predvsem kazniva dejanja s področja splošne kriminalitete. V analizo smo zajeli štiri skupine kaznivih dejanj in sicer:

- Kazniva dejanja zoper življenje in telo

- Kazniva dejanja zoper spolno nedotakljivost

- Kazniva dejanja zoper premoženje

- Kazniva dejanja povezana z mamili

Podrobneje smo obravnavali 23 značilnih kaznivih dejanj iz omenjenih skupin, vzporedno pa je predstavljena tudi kriminaliteta v Sloveniji po podatkih Ministrstva za notranje zadeve (2003). Primerjava stanja v Sloveniji in Ljubljanski urbani regiji jasno kaže na velik delež kriminalitete, ki odpade na območje Ljubljanske urbane regije (Tabela 1). Ta delež je še pomembnejši (41 \%), če obravnavamo samo kazniva dejanja s področja splošne kriminalitete.

Na osnovne značilnosti kriminala v Ljubljanski urbani regiji kaže struktura kaznivih dejanj po obravnavanih skupinah v odnosu do kriminala v celi Sloveniji, kjer je očiten je visok odstotek kaznivih dejanj zoper premoženje, ki predstavljajo skoraj $45 \%$ premoženjskega kriminala v Sloveniji. Na drugi strani pa so kazniva dejanja zoper življenje in telo ter spolno nedotakljivost na širšem območju Ljubljane razmeroma skromno zastopana. Takšna struktura kaznivih dejanj v Ljubljanski urbani regiji je nesporno povezana $\mathrm{z}$ ekonomsko močjo in centralno funkcijo tako Ljubljane kot glavnega mesta kot številnih bližnjih občin. 
Tabela 1: Kriminaliteta v Sloveniji in Ljubljanski urbani regiji leta 2002

Table 1: The criminality in Slovenia and in Ljubljana urban region in the year 2002

\begin{tabular}{|l|r|r|}
\hline Kazniva dejanja (KD) & Slovenija & LUR \\
\hline KD - vsa obravnavana & 84.145 & 31.799 \\
\hline Število KD/1000 prebivalcev & 42 & 65 \\
\hline KD - splošna kriminaliteta & 66.857 & 27.113 \\
\hline Število KD/1000 prebivalcev & 33 & 56 \\
\hline
\end{tabular}

Vir: MNZ, 2003.

Slika 2: Kazniva dejanja splošne kriminalitete v Sloveniji in Ljubljanski urbani regiji leta 2002

Figure 2: Criminal acts of general criminality in Slovenia and in Ljubljana urban region in the year 2002

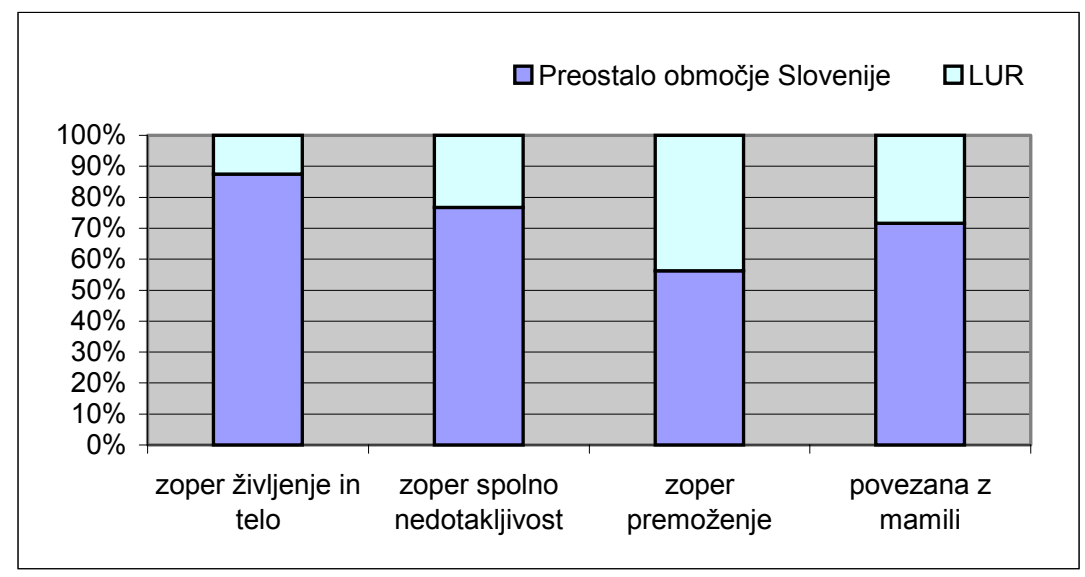

Vir: MNZ, 2003.

Na naraščajoč problem kriminalitete pri nas opozarja dejstvo, da se ljudje prisotnosti tovrstnega deviantnega vedenja vedno bolj zavedajo in da očitno narašča strah pred kriminalom. Raziskava v Ljubljani iz leta 2002 je pokazala, da se približno $30 \%$ prebivalcev prestolnice počuti ogroženih, med njimi pa prevladujejo tisti z manjšimi finančnimi zmožnostmi in nižjo izobrazbo (Meško, Areh, 2003).

\section{RAZPOREDITEV IN TRENDI KAZNIVIH DEJANJ $\checkmark$ LJUBLJANSKI URBANI REGIJI}

Število kaznivih dejanj splošne kriminalitete se od začetka 90-ih tako v Sloveniji kot na območju Ljubljanske urbane regije postopoma povečuje. Čeprav število posameznega kriminalnega dejanja iz leta $\mathrm{v}$ leto lahko precej niha, analize po skupinah kaznivih dejanj v vseh 24 občinah slovenske osrednje regije kažejo, da se bomo morali s problematiko kriminalitete $\mathrm{v}$ bodoče soočiti ne le v prestolnici ampak tudi v njenem suburbanem zaledju. 
Slika 3: Kazniva dejanja po občinah Ljubljanske urbane regije leta 2000 in 2002

Figure 3: Criminal acts in communities of the Ljubljana urban region in the year 2000 and 2002

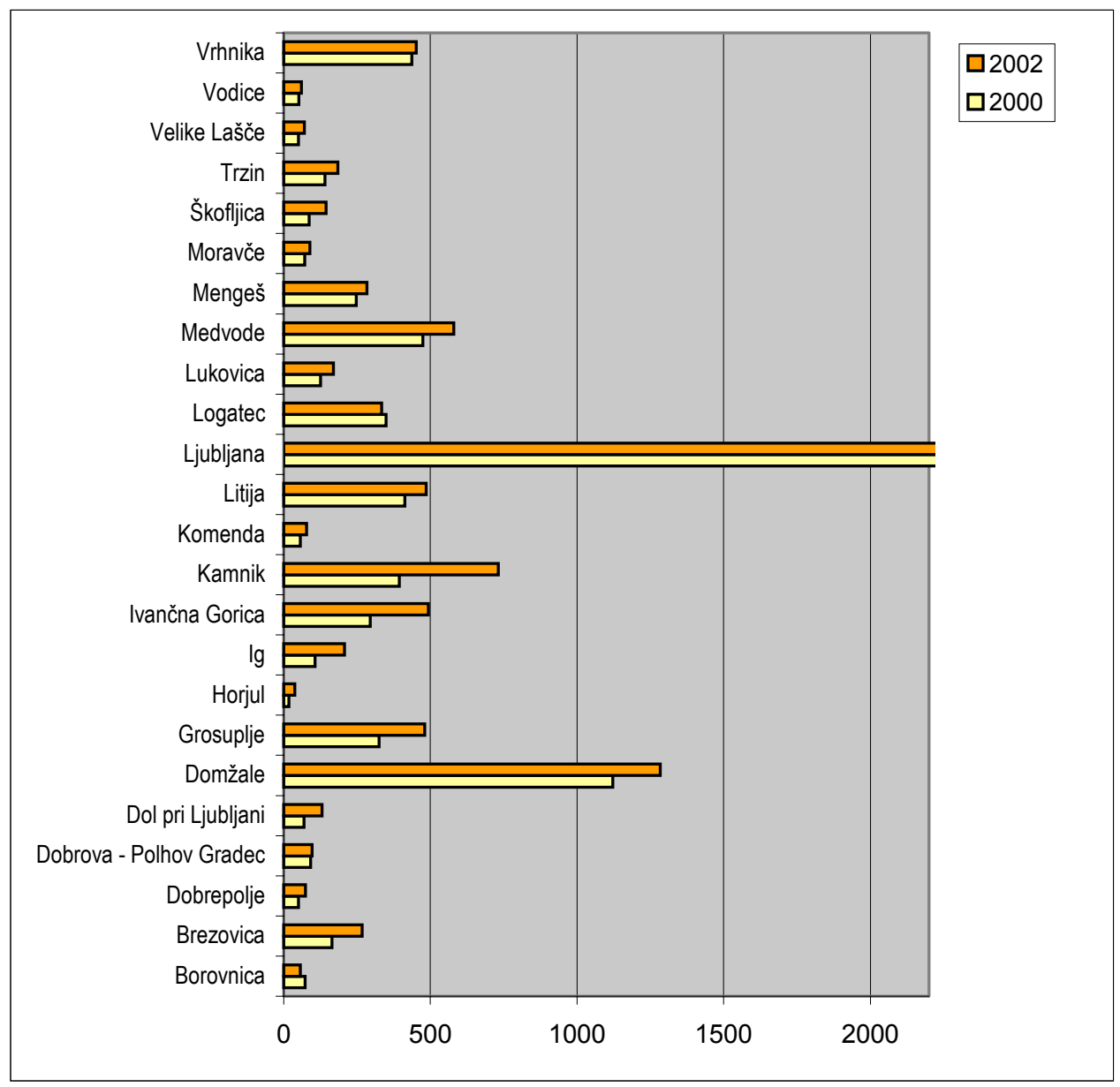

Vir: MNZ, 2003.

Porast kaznivih dejanj v prvih letih tega desetletja (2000 do 2002) je tako prisoten v kar 22 občinah Ljubljanske urbane regije. Izjemi sta samo občini v jugozahodnem delu, Borovnica in Logatec, kjer lahko statistično nekoliko pomembnejši upad pri občini Borovnica povezujemo s sicer zelo nizkim absolutnim številom kaznivih dejanj, pri občini Logatec pa je upad števila kaznivih dejanj malenkosten.

Na drugi strani je porast kaznivih dejanj najizrazitejši v sedmih občinah in sicer Kamnik, Ivančna Gorica, Škofljica, Brezovica, Ig, Dol pri Ljubljani in Horjul. Skokovit porast števila kaznivih dejanj pri slednjih dveh občinah je deloma pogojen z nizkimi absolutnimi vrednostmi števila kaznivih dejanj. 
Karta 1: Spreminjanje števila kaznivih dejanj po občinah LUR med letoma 2000 in 2002

Map 1: The changing of the number of criminal acts according to the LUR communes between the years 2000 and 2002

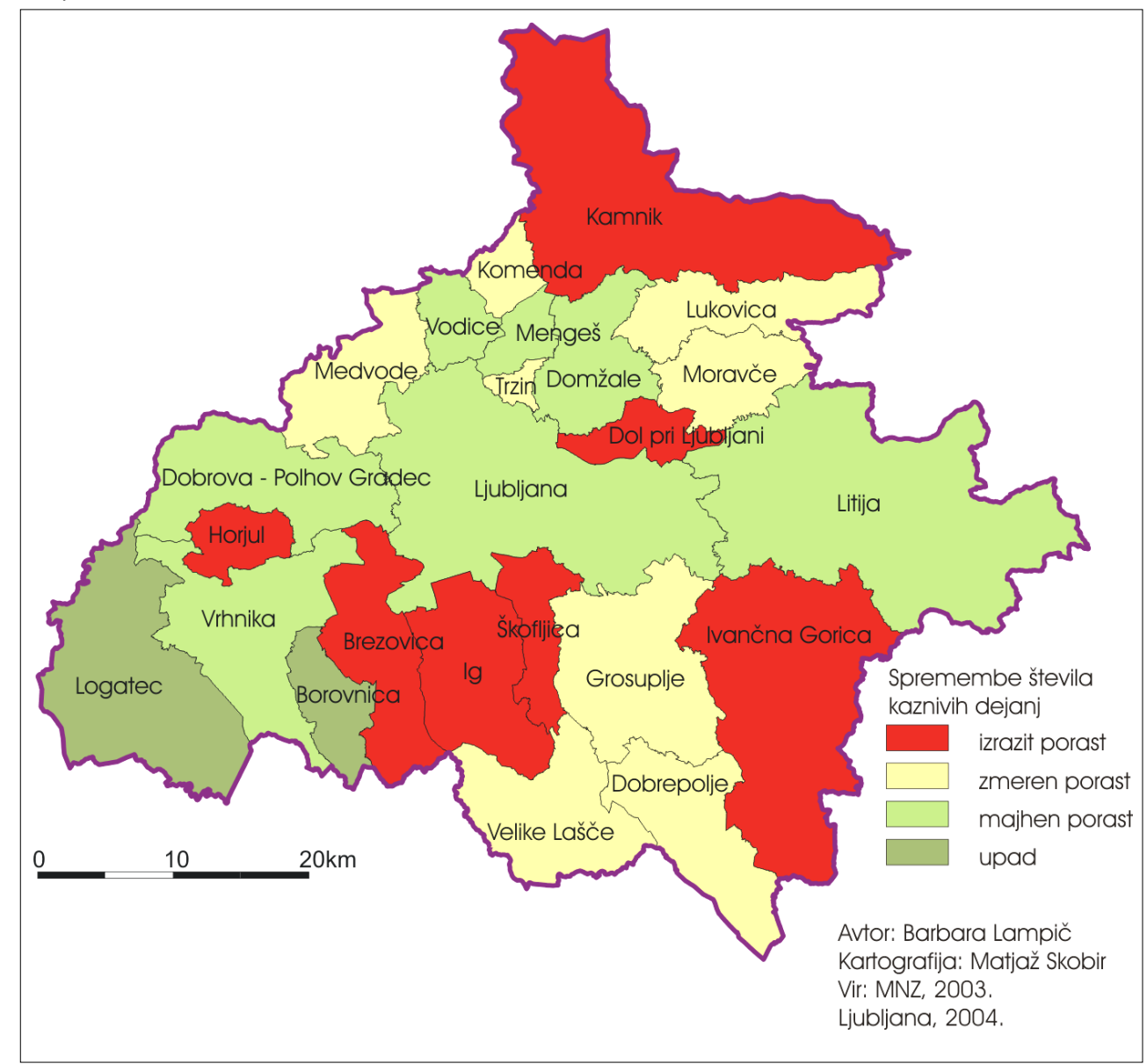

Vsekakor porast števila kaznivih dejanj v Ljubljanski urbani regiji še zdaleč ni zanemarljiv, saj je kar 16 od 24 občin v preučevanem obdobju preseglo povprečno rast kaznivih dejanj obravnavanega območja.

Prostorski prikaz gibanja števila kaznivih dejanj v občinah Ljubljanske urbane regije med letoma 2000 in 2002 kaže na največje spremembe v občinah severnega in jugovzhodnega dela regije. Izrazit in zmeren porast kaznivih dejanj izkazujejo predvsem občine, ki jih je zajel zadnji val suburbanizacije, ki pa še ni zaključen. To v prvi vrsti velja za Ivančno Gorico, Grosuplje, Škofljico, Ig, Velike Lašče, Dobrepolje na jugu in jugovzhodu ter Komendo, Lukovico, Moravče in Dol pri Ljubljani na severu Ljubljanske urbane regije. Kamnik in Brezovica še vedno izkazujeta izrazit porast kriminalitete, čeprav tu procesi suburbanizacije z različno intenziteto trajajo že od 80 -ih let prejšnjega stoletja. 
Spreminjanje kriminalitete po občinah smo primerjali tudi s podatkom o številu izdanih gradbenih dovoljenj (v obdobju 1998 in 2002). Poleg podatka o gibanju prebivalstva lahko število izdanih gradbenih dovoljenj (za novogradnje in obnove stanovanjskih in drugih poslopij) kaže na območja z izrazito razvojno dinamiko. Večina občin Ljubljanske urbane regije $\mathrm{z}$ izrazito ali zmerno rastjo kriminalitete je hkrati območje intenzivnih novogradenj. Samo v treh od petnajstih občin, kjer se je kriminaliteta najbolj povečala, ni pomembnejše povezave med rastjo kaznivih dejanj in številom izdanih gradbenih dovoljenj. To velja za občino Horjul (izrazito majhna občina) ter občini Medvode in Kamnik.

Tabela 2: Število kaznivih dejanj po občinah LUR leta 2000 in 2002

Table 2: The number of criminal acts in communities of the Ljubljana urban region in the year 2000 and 2002

\begin{tabular}{|l|r|r|r|r|}
\hline Občina & $\begin{array}{c}\text { Št. preb. } \\
2002\end{array}$ & $\begin{array}{c}\text { Št. KD } \\
2000\end{array}$ & $\begin{array}{c}\text { Št. KD } \\
2002\end{array}$ & $\begin{array}{c}\text { KD na } \\
1000 \text { preb. }\end{array}$ \\
\hline Borovnica & 3839 & 73 & 57 & 14,8 \\
\hline Brezovica & 9334 & 165 & 267 & 28,6 \\
\hline Dobrepolje & 3544 & 50 & 74 & 20,9 \\
\hline Dobrova - Polhov Gradec & 6691 & 91 & 97 & 14,5 \\
\hline Dol pri Ljubljani & 4341 & 69 & 130 & 29,9 \\
\hline Domžale & 29902 & 1122 & 1284 & 42,9 \\
\hline Grosuplje & 15665 & 325 & 481 & 30,7 \\
\hline Horjul & 2622 & 17 & 38 & 14,5 \\
\hline Ig & 5445 & 107 & 207 & 38,0 \\
\hline Ivančna Gorica & 13567 & 295 & 493 & 36,3 \\
\hline Kamnik & 26477 & 394 & 732 & 27,6 \\
\hline Komenda & 4451 & 56 & 78 & 17,5 \\
\hline Litija & 19120 & 413 & 486 & 25,4 \\
\hline Ljubljana & 265881 & 22470 & 25008 & 94,1 \\
\hline Logatec & 11343 & 349 & 334 & 29,4 \\
\hline Lukovica & 4972 & 126 & 169 & 34,0 \\
\hline Medvode & 14161 & 474 & 580 & 41,0 \\
\hline Mengeš & 6662 & 247 & 284 & 42,6 \\
\hline Moravče & 4508 & 72 & 89 & 19,7 \\
\hline Škofljica & 7119 & 86 & 144 & 20,2 \\
\hline Trzin & 3385 & 140 & 185 & 54,7 \\
\hline Velike Lašče & 3735 & 50 & 70 & 18,7 \\
\hline Vodice & 3871 & 52 & 60 & 15,5 \\
\hline Vrhnika & 488364 & 27680 & 31799 & 65,1 \\
\hline LUR & & & & \\
\hline & & 437 & 452 & 25,5 \\
\hline Vura & & & & \\
\hline
\end{tabular}

Vir: SURS 2002, MNZ 2003. 
Poleg občin Borovnice in Logatca, kjer smo že omenili upad kaznivih dejanj, se je kriminaliteta povečala le malo v sedmih občinah. V to skupino poleg Mestne občine Ljubljana uvrščamo še občine Domžale, Mengeš, Vrhnika, Litija, Dobrova - Polhov Gradec in manjšo občino na obrobju Ljubljanske urbane regije, Vodice.

Ob upoštevanju zgolj absolutnih vrednosti, pa je slika kaznivih dejanj v Ljubljanski urbani regiji povsem drugačna. Največ kaznivih dejanj je evidentiranih v osrednjem delu (Mestna občina Ljubljana s kar 76, 6 \% vseh oziroma 81,1 \% kaznivih dejanj splošne kriminalitete v Ljubljanski urbani regiji) oziroma severnem in severozahodnem delu regije, na območju Kamnika, Domžal in Medvod (Karta 2).

Karta 2: Kazniva dejanja po občinah LUR v letu 2002

Map 2: Criminal acts according to the LUR communes in 2002

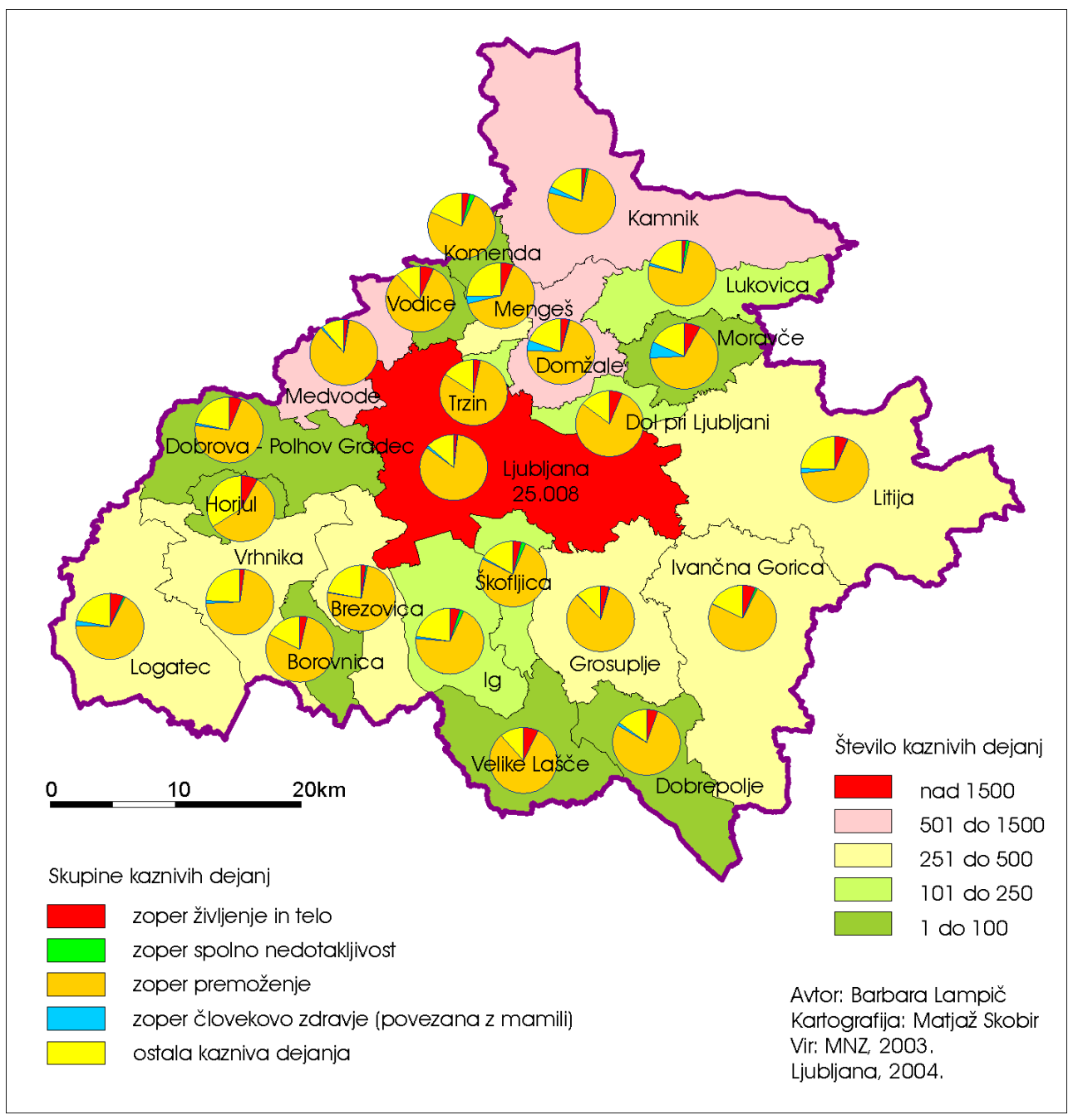


Ljubljanska urbana regija pa je, z izjemo izstopajočega osrednjega območja Mestne občine Ljubljana, mnogo bolj homogena po gostoti kaznivih dejanj na 1000 prebivalcev. Na račun velike zgostitve kriminalitete v sami Ljubljani, je povprečno število kaznivih dejanj v Ljubljanski urbani regiji kar 65 (v Mestni občini pa 94). Tej vrednosti se najbolj približajo samo občine Trzin, Domžale, Mengeš in Medvode v neposrednem urbanem zaledju Ljubljane.

V kar sedmih občinah (Borovnica, Dobrova - Polhov Gradec, Horjul, Komenda, Velike Lašče in Vodice) pa število kaznivih dejanj na 1000 prebivalcev ne presega 20. Z izjemo občine Dobrova - Polhov Gradec so vse majhne, z manj kot 5.000 prebivalcev.

Karta 3: Število kaznivih dejanj na 1000 prebivalcev po občinah LUR

Map 3: The number of criminal acts per 1000 inhabitants according to the LUR communes

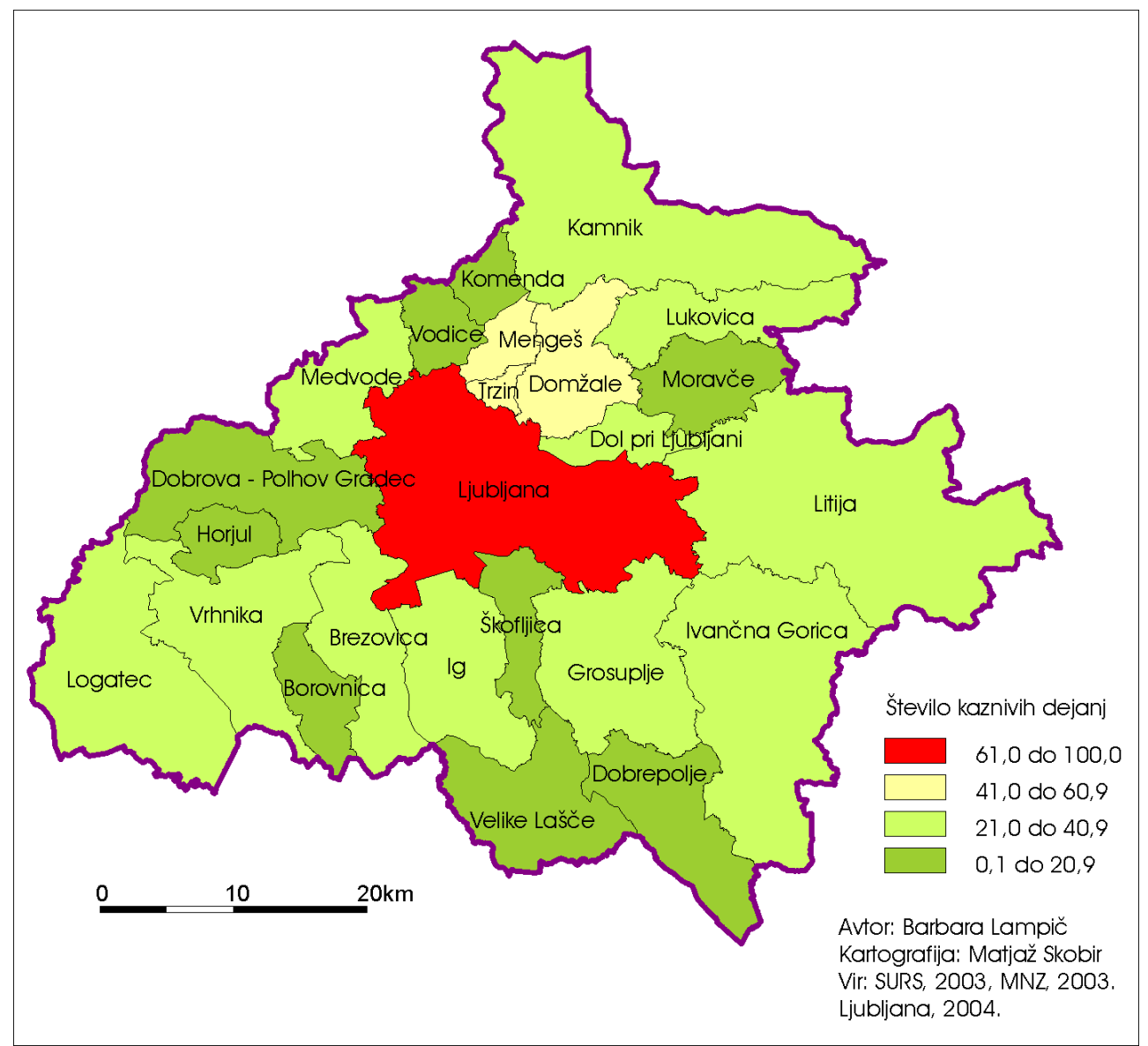

Manj enotna pa je karta števila kaznivih dejanj na 1000 prebivalcev po krajevnih skupnostih Ljubljanske urbane regije. Poleg izstopajočega mestnega dela Ljubljane, kjer je v posameznih krajevnih skupnostih število kaznivih dejanj na 1000 prebivalcev celo višje od 100, po- 
leg urbanih središč občin Domžale, Kamnika in Medvod izraziteje izstopajo tudi posamezni deli (krajevne skupnosti) občin Vrhnika, Ig, Grosuplje, Ivančna Gorica, Dol pri Ljubljani in Lukovica. Po gostoti kaznivih dejanj pa $\mathrm{v}$ še do pred kratkim pretežno podeželskih občinah izstopajo predvsem tiste krajevne skupnosti, ki v zadnjih letih doživljajo visok priliv prebivalstva predvsem iz Ljubljane.

Karta 4: Število kaznivih dejanj na 1000 prebivalcev po krajevnih skupnostih LUR v letu 2002

Map 4: The number of criminal acts per 1000 inhabitants according to the LUR local communes in 2002

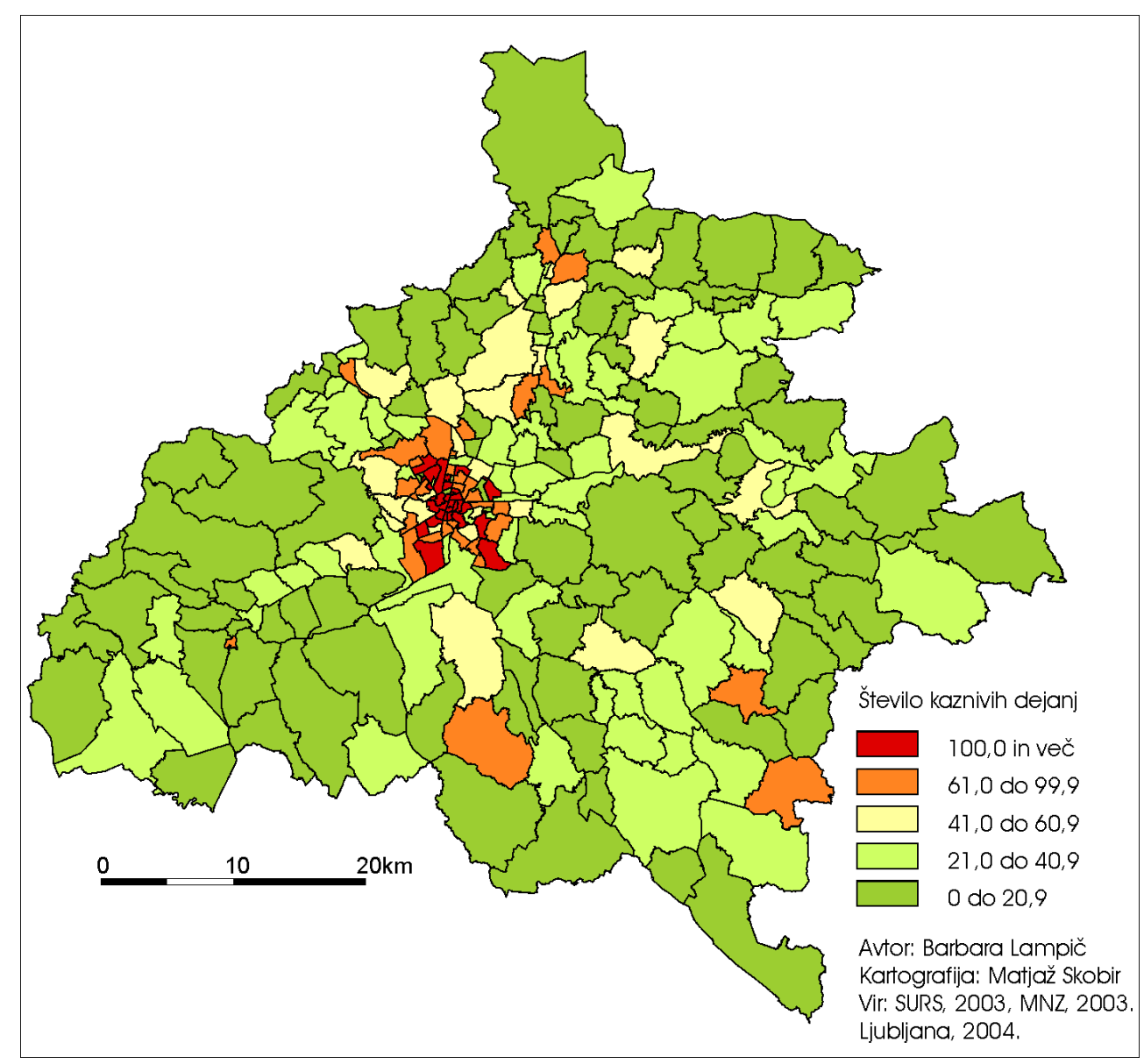

\section{ZAKLJUČEK}

Naraščanje kriminalitete po letu 1990 je prisotno v celi Sloveniji, porast kaznivih dejanj pa je še posebej izrazit $\mathrm{v}$ Ljubljanski urbani regiji, kjer prihaja tudi do njihovih pomembnih 
prostorskih prerazporeditev. Daleč najugodnejši gospodarski kazalci, izrazita koncentracija človeškega kapitala ter ugodna prometna lega na križišču slovenskih in evropskih prometnih koridorjev, to osrednjo regijo po razvojnih možnostih v slovenskem merilu uvrščajo na prvo mesto (Rebernik, 2003). Skupaj z gospodarsko rastjo in selitvenim prirastom pa narašča tudi stopnja kriminalitete, predvsem število kaznivih dejanj zoper premoženje. Lahko že govorimo o naraščanju ogroženosti prebivalstva, hkrati pa se povečuje tudi strah pred kaznivimi dejanji, kar lahko preraste v problem širših razsežnosti. Strah pred kriminaliteto je namreč pomemben dejavnik, ki vpliva na zmanjšanje zaupanja prebivalstva $\mathrm{v}$ skupnost, omejuje gospodarski razvoj in določene investicije, predvsem pa pomembno vpliva na kakovost življenja (Meško, Areh, 2003). Kriminaliteta, ki še do pred kratkim v Ljubljani ni predstavljala faktorja diferenciacije mesta z vidika kvalitete bivanja, tako v mestni kot tudi primestnih občinah že dosega razsežnosti, ko bo potrebno načrtno uvajanje primernih ukrepov za njeno omejevanje oziroma zmanjševanje.

Vsekakor porast števila kaznivih dejanj v Ljubljanski urbani regiji še zdaleč ni zanemarljiv, saj je v obdobju 2000 do 2002 kar 16 od 24 občin preseglo povprečno rast kaznivih dejanj v Ljubljanski urbani regiji. Povečanje je predvsem izrazito na območjih, ki jih je zajel zadnji val suburbanizacije.

\section{Literatura}

Knox, P., 1995: Urban Social Geography. Longman Scientific and Technical. Essex. 350.

Krevs, M., 2002: Geografski vidiki življenjske ravni prebivalstva Ljubljane. Geografija Ljubljane. Ljubljana. 117-132.

Meško, G., Areh, I., 2003: Strah pred kriminaliteto v urbanih okoljih. Revija za kriminalistiko in kriminologijo. Letnik 54, št. 3. Ljubljana. 256-264.

Musek Lešnik, K., 1998: Psychological Aspects of Increasing Crime in Transitional Countries. Policing in Central and Eastern Europe. Ljubljana. 385-401.

Ravbar, M., 2002: Suburbanizacijske težnje v razvoju prebivalstva in delovnih mest v ljubljanski mestni regiji. Geografija Ljubljane. Ljubljana. 215-233.

Rebernik, D., 2003: Ljubljanska urbana regija - razvojni trendi, problemi in možnosti. Dela 19. Priložnosti in možnosti regionalnih struktur na poti k združeni Evropi. Ljubljana. 165-176.

Rebernik, D., 2002: Socialnogeografska zgradba in preobrazba Ljubljane. Geografija Ljubljane. Ljubljana. 85-116.

Svetek, S., 2003: Kriminaliteta in kriminalistično delo v letu 2002. Revija za kriminalistiko in kriminologijo. Letnik 54, št. 2. Ljubljana. 115-124.

Špes, M., Cigale, D., Lampič, B., 2002: Izstopajoči okoljski problemi v Ljubljani. Geografija Ljubljane. Ljubljana. 53-84.

Uradni list RS 63/94: Kazenski zakonik RS. 


\section{CRIMINALITY AS AN INCREASINGLY IMPORTANT FACTOR OF THE QUALITY OF LIVING IN THE LJUBLJANA URBAN REGION}

\section{Summary}

The Ljubljana urban region, in which more than $25 \%$ of the whole population of Slovenia live, with the capital represents the central economic developmental area of the country. Criminal acts in Slovenia are increasing but their increase is most significant in the Ljubljana urban region, where in 2002 their percentage already exceeded $40 \%$ of all criminal acts in Slovenia. As a consequence of suburbanization we can above all treat criminal acts belonging to the field of general criminality, among which criminal acts against property have the most important place. This is reflected in an important share (almost $45 \%$ of the financial crime in Slovenia) of the common criminal acts structure of the Ljubljana urban region.

The analyses according to the groups of criminal acts in 24 communes of the Slovene central region show that in the future we will have to deal with the problem of criminality not only in the capital but also in its suburbs. The increase of criminal acts in the first years of this decade (2000 to 2002) is thus present in 22 communes whereas in 16 communes it exceeded the average growth of criminal acts of the whole Ljubljana urban region. The spatial presentation of the criminal acts movement in the area dealt with, indicates biggest changes in the communes of the northern and south-eastern part of the urban region. Dramatic and moderate increases of criminal acts are above all shown in communes captured by the last wave of suburbanization, which is not finished yet. This in the first place applies to Ivančna Gorica, Grosuplje, Škofljica, Ig, Velike Lašče, Dobrepolje in the south and southeast and Komenda, Lukovica, Moravče and Dol pri Ljubljani in the north of the Ljubljana urban region. Except in the Borovnica and Logatec communes, where the decrease of criminal acts was marked, the criminality increased slightly only in seven communes. 